\title{
Okul öncesi dönem çocuklarının prososyal davranışlarının bazı değişkenler açısından incelenmesi*
}

\section{An analysis of several variables that affect preschool children's prosocial behavior}

Makale Geçmişi

Geliş : 10 Mart 2020

Düzeltme : 7 Temmuz 2020

Kabul : :24 Ağustos 2020

\section{Makale Türü}

Arastrma Makalesi
Article History

Received :10 March 2020

Revised : : July 2020

Accepted :24 August 2020

\section{Article Type}

Research Article

\author{
Naşide Nur Karaman ${ }^{1}$, F. Çağlayan Dinçer ${ }^{2}$
}

Öz: Prososyal davranışlar, başkalarına yarar sağlamaya yönelik olarak gerçekleştirilen ve tamamen gönüllü eylemler olarak tanımlanmaktadır. Bu araştırmada, okul öncesi dönem çocukların prososyal davranışlarının yaş, cinsiyet, kardeş sayısı, okul öncesi eğitim kurumuna devam süresi ve anne-babanın öğrenim düzeyi, ebeveyn tutumları açısından incelenmesi ve bu değişkenlerin prososyal davranışlar üzerindeki yordayıcı etkisinin belirlenmesi amaçlanmışırı. Çalışma, 25-72 ay aralığındaki 290 çocuk ile yürütülmüștür. Verilerin toplanmasında "Demografik Bilgi Formu", "Çocuk Prososyallik Ölçeği (ÇPÖ)" ve "Ebeveyn Tutum Ölçeği (ETÖ)" kullanılmıştır. Verilerin analizinde t-testi, ANOVA, Pearson moment çarpım korelasyon katsayısı ve aşamalı çoklu regresyon analizi kullanılmıştır. Araştırma sonuçlarına göre; kız çocuklarının ÇPÖ'den almış oldukları puanların erkek çocuklara göre anlamlı olarak daha yüksek olduğu; çocuğun yaşı büyüdükçe prososyal davranış puan ortalamalarının arttığı; 6 aydan fazla okul öncesi eğitim kurumuna devam eden çocukların prososyal davranış puan ortalamalarının, yeni başlayanlara göre daha yüksek olduğu bulunmuştur. Demokratik ebeveyn tutumu, cinsiyet ve yaş değişkenleri ÇPÖ puanlarının yaklaşık \%14'ünü açıklamaktadır.

Anahtar Kelimeler: Prososyal davranışlar, Ebeveyn tutumları, Okul öncesi dönem

Abstract: Prosocial behaviors are defined as actions performed voluntarily to benefit others. This study aimed first to investigate the prosocial behavior of preschool children and these variables: age, gender, number of siblings, duration of preschool attendance, parental education levels, and parental attitudes. It also aimed to determine if these variables predict prosocial behaviors. Theis study was conducted with 290 children who were 25 to 72 months old. A Demographic Information Form, the Child Prosociality Scale (CPS), and the Parenting Attitude Scale (PAS) were the data collection tools. The data were analyzed using the t-test, ANOVA, Pearson's Product Moment Correlation and stepwise multiple regression analysis. The girls scored significantly higher on the CPS. The children's mean CPS scores increased with age, and children who had attended preschool for six months or more scored higher on the CPS than beginners. Democratic parental attitude, gender and age accounted for approximately $14 \%$ of the CPS scores.

Keywords: Prosocial behaviors, Parenting attitudes, Preschool period 


\section{SUMMARY}

\section{Introduction}

Prosocial behaviors are critical for the socialization of children. Prosocial behaviors refer to entirely voluntary actions, that are not externally driven by social demands, and are intended to help or benefit an individual or a group (Eisenberg and Mussen, 2003). These behaviors require the ability to recognize other people's needs, to take responsibility and act accordingly (Hägglund, 1993). In other words, prosocial behaviors involve being aware of other people's feelings, working with them, and being sensitive to their needs or wishes (Hay and Cook, 2010). Bee and Boyd (2009) define prosocial behaviors as community oriented, which is why they are entirely voluntary and intentioned to benefit others.

This study investigated the prosocial behavior of preschool children and these variables: age, gender, number of siblings, duration of preschool attendance, parental education levels, and parental attitudes. It also aims to determine if these variables predict prosocial behaviors. This study sought answers to these research questions:

1. Does there any significant difference between the prosocial behavior of preschool children vary with their age, gender, number of siblings, duration of preschool attendance, parental education levels, and parental attitudes?

2. Do any of these variables predict the prosocial behaviors of preschool children?

\section{Method}

The correlational survey model was used in this study. Its sample consisted of 290 children, 132 girls and 158 boys, who were attending preschools under the Directorate of National Education in the south-central Turkish city of Kilis.

The data were gathered using a Demographic Information Form, the Child Prosociality Scale (CPS) and the Parenting Attitude Scale (PAS), all of which were filled out by the children's mothers.

The Demographic Information Form contains information about parental education level and the age, gender, the number of siblings and duration of preschool attendance.

The Child Prosociality Scale (CPS) was developed by Bower (2012) to determine the prosociality levels of preschool period children. Bağcı and Öztürk Samur (2016) adapted the scale into Turkish and confirmed its validity and reliability. This has three separate versions for mothers, fathers, and teachers. All three versions are one-dimensional. This Likert-type, scale rated the extent of children's prosocial behavior from 1 to 5 (never, rarely, sometimes, usually, and always). High scores on the scale in dicate more prosocial behaviors. The teachers' versions of the scale and the fathers' version consist of 22 items, and the mothers' version consists of 21 items. 
The Parenting Attitude Scale (PAS) was developed by Karabulut Demir and Sendil (2008) to measure the parenting attitudes of parents of two to six year-olds. The scale consists of 46 items in four sub-dimensions (democratic, authoritarian, overprotective, and permissive). High scores on a sub-dimension mean that the parents have the parenting attitude it concerns.

The data were analyzed using the t-test, ANOVA, Pearson's Product-Moment Correlation and stepwise multiple regression analysis.

\section{Results}

The children's prosocial behavior varied significantly with age $[\mathrm{F}(3,286)=3.19, \mathrm{p}<.05]$. Their prosocial behavior mean scores increased with age (25-35 months, $\bar{X}=3,52$; 36-47 months, $\bar{X}=3,66$; 48-59 months, $\bar{X}=3,78 ; 60-72$ months, $\bar{X}=4,11)$. The children's CPS scores also varied significantly by gender $[t(288)=2.64$, $\mathrm{p}<.05]$ and duration of preschool attendance $[\mathrm{t}(288)=2.76, \mathrm{p}<.05]$. Girls' prosocial behavior mean scores $(\bar{X}=3.85)$ were higher than boys' prosocial behavior mean scores $(\bar{X}=3.67)$. The CPS scores of the children who had attended preschool for six months or more $(\bar{X}=3.81)$ were higher than beginners $(\bar{X}=3.6)$. The chidren's CPS scores did not vary significantly by number of siblings $[\mathrm{t}(288)=1.39, \mathrm{p}>.05]$, maternal education $[\mathrm{F}(2,287)=1.6, \mathrm{p}>.05]$ and paternal education level $[\mathrm{F}(2,287)=.51, \mathrm{p}>.05]$. Stepwise multiple regression analysis determined that the children's CPS scores were predicted positively and significantly by democratic parental attitudes $(\beta=.421 ; \mathrm{p}<.05)$, gender $(\beta=.173 ; \mathrm{p}<.05)$, and age $(\beta=.320 ; \mathrm{p}<.05)$. These three variables accounted for approximately $14 \%$ of the children's CPS scores.

\section{Conclusion and Discussion}

The older the children were the higher their mean prosocial behaviors scores were. The girls scored significantly higher than the boys. The children who had attended preschool for six months or more got higher scores than beginners. The statistically significant differences in the children's CPS scores due to parental education levels or number of siblings. However, the children with one or more siblings had higher mean prosocial scores than those with no siblings. Democratic parental attitudes, gender and age were found to predict prosocial behaviors. The children got .421 points more than the others if they had one more points for democratic parenting. Therefore, parents should be involved in training programs to help them adopt democratic parental attitudes. While the other variables remained the same, the girls got .173 more points than the boys on the CPS. The prosocial behaviors scores of the 60-72 months old children were .320 points higher than the 25-35 months old child. The duration of preschool attendance also affected the children's prosocial behavior, so preschool education programs should support by prosocial behaviors, and the long-term effects of behaviors should be investigated. Educational programs that support prosocial behavior should be designed on the basis of further experimental studies. Initiatives should also be made to improve the prosocial behavior of boys, while continuing to besides promote the prosocial behavior of girls. In addition to these initiatives, boys may need further support to help them engage in comforting behaviors, sharing, and empathizing with and helping others. Finally, it is clear that the CPS scores do not have a 
statistically significant difference with neither the education level of parents nor how many siblings the child has. 


\section{GİRIŞ}

Toplumları oluşturan bireylerin bir araya gelmelerini ve bir arada kalmalarını sağlayan pek çok değer vardır. Bireylerin birbirleriyle olumlu ilişkiler içine girmesi ve bu ilişkileri sürdürebilmesi için önemli olan bu değerler, toplumların dolayısıyla da bireylerin daha sağlam ve güçlü olmalarına da yardım etmektedir. Bu açıdan olumlu sosyal davranışlar olarak da adlandırılan prososyal davranışların, okul öncesi dönemde gelişimi oldukça önemli bir yere sahiptir. Prososyal davranışlar, dışsal olarak toplumsal talepler tarafindan yönlendirilmeden başka bir bireye veya gruba yardım etmeye veya fayda sağlamaya yönelik olarak tamamen gönüllü yapılan eylemlerdir (Eisenberg ve Mussen, 2003). Bu davranışlar, başka bir kişinin ihtiyacını tanıma, böyle bir durumda sorumluluk alma ve bu yönde hareket etme yeteneğini gerektirir (Hägglund, 1993). Bir diğer ifadeyle prososyal davranışlar, başkalarının duygularını hissetme, onlarla birlikte çalışmayı ve onların ihtiyaçlarına veya isteklerine duyarlı olmayı içerir (Hay ve Cook, 2010). Bee ve Boyd (2009) tarafından toplum yanlısı davranışlar olarak tanımlanan prososyal davranışların belirleyici özelliği, başkalarına yarar sağlaması için kasıtlı ve niyetli olarak yapılması ve tamamen gönüllü olmasıdır. Çocuklar, başkalarının refahı için duydukları kaygı ile içsel olarak motive olduklarında prososyal davranışlar sergilerler (Hepach, Vaish ve Tomasello, 2013). Başkalarına yarar sağlayan bu davranışlar kişi için içsel bir motivasyon sağlamakla birlikte bir dışsal kaynağın etkisi ya da ödül elde etmek ve cezadan kaçmak için gerçekleşmez. Hay ve Cook (2010), prososyal davranışları diğer insanlarla iletişim kurmanın olumlu yolu olarak açıklamaktadır. Prososyal davranışlar; empati, perspektif alma, teselli etme, yardım etme, iş birliği yapma, bağışlama ve paylaşma gibi eylemleri içerir (Sterling Honig, 1982). Perspektif alma becerileri gelişmiş olan çocukların akran etkileşimleri sırasında prososyal davranışlar sergileme eğilimlerinin daha fazla arttı̆̆1 da belirtilmektedir (Cigala, Mori ve Fangareggi, 2014). Birey bu olumlu davranışları göstererek toplum içinde kendine yer bulmaktadır. Nazik, yardımsever, şefkatli ve yararlı davranışlar, rahatlatıcı-teselli edici, özgeci davranışlar, birçok insan tarafindan insan doğasının en iyi özellikleri olarak kabul edilmektedir (Hastings, Utendale ve Sullivan, 2007).

Erken çocukluk döneminde edinilen prososyal davranışlar, çocukların olumlu sosyalleşme sürecinde kritik bir öneme sahiptir. Prososyal davranışlar, sosyalleşme sürecinin bir parçası olmakla birlikte daha ileri bir beceri olarak görülmektedir (MEB, 2013). Birey, toplumun değer yargılarını gözeterek yine toplum tarafından kabul gören davranışları tercih ederek prososyal davranışlar sergilediğinde; bu durum ahlaki gelişimin olumlu yönü olarak ifade edilmektedir (Beaty, 1998). Okul öncesi dönem çocuklarının sosyal normları içeren ahlaki ve sosyal kural bilgisini öğrenmeleri, onların topluma ve sosyal hayata karşı davranışlarının belirlemektedir. Davranışların başkalarının refahı üzerinde doğal etkisini ahlaki kural bilgisi belirler. Bir davranışın yeterliliğinin sosyal bağlam 
içinde belirlenmesi ise sosyal kural bilgisidir. Dereli (2019) tarafindan çocukların prososyal davranışlarının, saldırganlık türlerinin, ahlaki ve sosyal kural bilgi algılarının incelendiği çalışmada; çocukların ahlaki ve sosyal kural bilgisini algılama puanlarının, prososyal davranışları ve saldırganlık türü puanları anlamlı düzeyde yordadığı belirlenmiştir. Buna göre ahlaki ve sosyal kural bilgisi algıları yüksek olan çocukların daha fazla prososyal davranış sergilediği ve düşük olan çocukların ise daha fazla sayıda saldırganlık türü davranış sergilediği sonuçlarına ulaşılmıştır. Ayrıca saldırganlık türlerinden ilişkisel saldırganlığın düşük prososyal davranış puanları ile ilişkili olduğu da bulunmuştur (Swit ve McMaugh, 2012). Diğer bir deyişle çocukların ahlaki ve sosyal kural bilgisi algıları ne kadar arttırılırsa prososyal davranışları daha sık sergileyecekleri ve böylelikle de gösterdikleri saldırganlık türlerinin de azalmış olduğu gözlemlenecektir. Kakavoulis (1998) çocukların prososyal yönden gelişim göstermelerinde prososyal davranış programlarının geliştirilmesinin etkili olacağını belirtmiştir. Oyun temelli öğrenme etkinliklerinin okul öncesi dönem çocukların olumlu öğrenme ve prososyal davranışları üzerindeki etkisinin araştırıldığı bir çalışmada; oyun temelli öğrenme etkinliklerin deney grubu çocuklarında prososyal davranışların ortaya çıkma sıklığını arttırdığı bulunmuştur (Chin ve Zakaria, 2015). Acar ve Torquati (2012) doğa temelli sembolik oyununun çocukların prososyal davranışlanının gelişimini nasıl desteklediğini incelemiş, doğanın çocukların diğer canlıların ihtiyaçlarını anlamalarına yardımcı olduğu ve akranlarıyla oyun oynamalarının prososyal davranışlarını geliştirmelerini desteklediği yönünde sonuçlar elde etmişlerdir. Ayrıca çocukların boylamsal olarak prososyal davranışlarının incelendiği bir çalışmada, okul öncesi sınıflarda gözlemlenen prososyal davranışların, ergenlik dönemindeki prososyal davranışları öngörmede belirleyici olduğu bulunmuştur (Eisenberg ve diğerleri, 1999). Bununla birlikte erken çocukluk döneminde gösterilen prososyal davranışların, ergenlik dönemindeki akademik başarı ve akran ilişkileri üzerinde güçlü ve olumlu bir etkisi olduğu da belirlenmiştir (Caprara ve diğerleri, 2000).

Prososyal davranışların hangi yaş aralığında ortaya çıktığı konusundaki araştırmalarda farklı görüşler mevcuttur. Conte, Grazzani ve Pepe (2018), prososyal davranışların yaşamın ikinci yılında, Brownell (2013) başkalarına yardım etme, sıkıntılarına cevap verme, paylaşma ve iş birliği yapma vb. davranışların 12 ile 24 aylık çocuklarda, Vaish, Carpenter ve Tomasello (2009) ise, sosyal mesajlara karşı sempati göstermenin 18-25 aylık çocuklarda ortaya çıktığını belirtmiştir. Genel olarak prososyal davranışların erken çocukluk döneminin ikinci yılında, başkalarının duygularını anlamalarına yönelik olan eylemler sergilemeleri (Svetlova, Nichols ve Brownell, 2010) ve çevresindekilere yardım etme (Warneken, 2015) şeklinde ortaya çıktığı ifade edilmektedir. 
Prososyal davranışları etkileyen faktörler, genetik ve çevresel faktörler olarak ele alınmaktadır (Knafo ve Plomin, 2006). Prososyal davranışları etkileyen genetik faktörler olarak çocuğun cinsiyeti ve yaşı (Eisenberg ve Fabes, 1998), çevresel faktörler olarak akran ilişkileri, eğitim ortamı, kültür (Altıntaş ve Bıçakçı, 2017), ebeveynlerin prososyal davranışları ve çocuğun kardeş sayısı (Bağcı ve Öztürk Samur, 2016) sayılabilir. Paylaşma, sosyal ilgi, nezaket, yardım etme ve empati gibi prososyal davranışların genetik ve çevresel kökenleri araştırılmıştır. Prososyal davranışların genetikten büyük ölçüde etkilenen bir fenotipe sahip olduğu söylenebilir. Genetik olarak empatiye yatkınlık, prososyal davranışları etkileyebilir. Paylaşılan çevre içinde ailelerin prososyal davranışları teşvik etmeleri her zaman empati yaptıkları anlamına gelmediği gibi; paylaşılmayan çevre içindeki utangaç mizaca sahip bir çocuğun başkalarına yardım etme konusunda geri planda kalması, onun empati yapmasına engel olmamaktadır. Fakat bu gibi durumlar çocukların prososyal davranışlarını göstermelerinde farklılıklara neden olmaktadır. Genetik ve çevresel faktörlerde yapılacak olan değişimlerin çocukların yardım etme ve paylaşma gibi prososyal davranışlar gösterme eğilimlerinde farklılıklara neden olduğu sonucuna ulaşılmıştır. Farklı prososyal eylemler farklı motivasyonları yansıtabilir. Diğer bir deyişle genetik etkilerin büyüklüğü, paylaşılan ve paylaşılmayan çevre prososyal davranışları etkilemektedir (Knafo-Noam ve diğerleri, 2015). Diğer bir açıdan kültürün prososyal davranışlar üzerine etkisinin incelendiği çalışmalar da mevcuttur. Amerika Birleşik Devletleri, Türkiye ve Polonya olmak üzere üç farklı ülkedeki çocukların prososyal davranışlarının incelendiği çalışmaya göre: Amerika'daki çocukların oyuncaklarını ve materyallerini paylaştıkları ve öğretmenlerine yardım ettikleri görülürken, Türkiye'de çocukların kibar sözler söyleme ve yardım davranışları gösterdikleri, Polonya'daki çocukların ise şefkat-sevgi gösterme ve teşvik etme davranışları sergiledikleri gözlemlenmiştir (Nowak-Fabrykowski, Dinçer, Lewandowskave ve Şen, 2013). Öte yandan okul öncesi dönemde ebeveyn davranışları ve çocuğun mizacı ile çocukların prososyal davranışları arasındaki ilişkilerin incelendiği bir çalışmaya göre Avustralyalı ve Türk çocukların benzer düzeyde prososyal davranışlar sergiledikleri de bulunmuştur (Yağmurlu, Sanson ve Köymen, 2005). İncelenen bu çalışmalarda prososyal davranışların farklı kültürlerde yer alan çocuklarda farklı prososyal davranışlar sergilemelerine neden olduğu sonucuna ulaşılmıştır. Ancak bu farklılıklara rağmen çocukların, benzer düzeylerde davranış sergiledikleri görülmektedir. Diğer bir deyişle çocukların prososyal davranış gösterme düzeyleri kültürel olarak örtüşse de davranışsal olarak farklılıklar içermektedir.

Prososyal davranışlar, okul öncesi yıllarda model alma ve taklit etme yoluyla kazanılmaktadır. Olumlu sosyal davranışlar model olarak gösterildiğinde ve teşvik edildiğinde; çocuklar, başkalarının ihtiyaçlarına saygı duymayı ve cevap vermeyi öğrenirler (Doescher ve Sugawara, 1989). Yetişkinlerin çocuklarına hangi durumda hangi davranışın uygun olduğunu ve neden böyle bir şekilde 
davranmanın gerekli olduğunu açıklayarak öğretmeleri gerekir. Örneğin; yardıma ihtiyacı olan birini gördüklerinde ebeveynin neden bu durumda yardım etmeleri gerektiğini çocuğuna açıklaması onun bu davranışı öğrenmesini ve onun da yardım etmesini sağlar. Ebeveynlerin çocukları ile konuşurken duygu ifadeleri kullanmaları, tartısmalarda duygularını tanımlamaları, çocukları duygular üzerinde düşünmeye yönlendirecek, onların başkalarının duygularına olan duyarlılıklarını artıracak, diğer kişilere karşı nasıl davranacaklarını öğrenmelerini sağlayacak ve erken prososyal davranışları destekleyecektir (Brownell ve diğerleri, 2013). Hastings, Utendale ve Sullivan (2007), sicak ve etkileşimli deneyimler yaşayan bireylerin yaşamları süresince diğer bireyleri anlama, yardım etme ve empati kurma konusunda gelişim gösterdiklerini bildirmiştir. Bu nedenle ailenin özgecilik, yardımseverlik, cömertlik gibi prososyal davranışları destekleyip desteklemediğine ve bu gibi davranışlarla çocukların içsel motivasyonlarının nasıl güçlendiğine dikkat edilmelidir (Eisenberg ve Mussen, 2003). Çocuklar prososyal davranışı öğrenirken diğer yandan bu tür davranışların sonuçlarını da öğrenmelidir (Mareš, 2017). Böylelikle ebeveynin sosyalleşme mesajına çocuğun etkin bir şekilde katılması sağlanmış olur (Hastings, Utendale ve Sullivan, 2007). Çocuklar toplum içinde kabul gören davranışları ilk önce ebeveynlerinden öğrenirler ve sosyalleşirler. Bu açıdan çocukların davranışlarının şekillenmesinde rol oynayan anne babaların çocuk yetiştirme tutumları, davranışları, uygulamaları, disiplinleri ve çocukla etkileşimleri onların gelişimleri üzerinde önemli rol oynamaktadır (Carlo ve Randall, 2001; Kandır ve Alpan, 2008).

Çocukların prososyal eğilimlerinin; ebeveynleri ile ilişkilerinin kalitesi, ebeveynin çocuk yetiştirme uygulamaları ve aile ortamının doğasından doğrudan etkilendiği belirtilmektedir (Eisenberg ve Mussen, 2003; Sterling Honig, 1982). Yapılan başka bir araştırmada aile içindeki duygusal iklimin; anne-çocuk ilişkisinin kalitesinin ve olumlu ebeveyn davranışlarının (López ve diğerleri, 1998; Pastorelli ve diğerleri, 2016), ebeveyn sıcaklığının (Williams ve Berthelsen, 2017) çocukların prososyal davranışları üzerindeki etkisini yordamakta olduğu sonucuna ulaşılmıştır. Ferreira ve diğerleri (2016) tarafindan yapılan okul öncesi çocukların anneleri, babaları ve öğretmenleri ile ilişkilerinin prososyal davranışlar üzerindeki etkisinin incelendiği çalışmada; baba ve öğretmenle olan ilişkilerin çocukların prososyal davranışlarıyla doğrudan bir ilişkisi olduğu saptanırken, anneçocuk ilişkisinin çocukların prososyal davranışlarıyla dolaylı olarak ilişkilendirildiği belirlenmiştir. Ayrıca güvenli bağlanan çocukların başkalarının ihtiyaçlarına daha duyarlı olduğu tespit edilmiştir (Beier ve diğerleri, 2019; Paulus, Becker, Scheub ve König, 2016). Literatür incelemeleri dikkate alındığında bu çalışmada; okul öncesi dönem çocukların prososyal davranışlarının yaş, cinsiyet, kardeş sayısı, okul öncesi eğitim kurumuna devam süresi ve anne-babanın öğrenim düzeyi, ebeveyn tutumları açısından incelenmesi ve bu değişkenlerin prososyal davranışlar üzerindeki yordayıcı 
etkisinin belirlenmesi amaçlanmaktadır. Yapılan bu çalışma ile aşağıdaki araştırma sorularına yanıt aranmıştır.

1. Okul öncesi dönem çocukların prososyal davranışları ile çocuğun yaşı, cinsiyeti, kardeş sayısı, okul öncesi eğitim kurumuna devam süresi; anne-babasının öğrenim düzeyleri, ebeveyn tutumları bakımından anlamlı bir farklılık var mıdır?

2. Yaş, cinsiyet, kardeş sayısı, okul öncesi eğitim kurumuna devam süresi ve anne-babasının öğrenim düzeyi, ebeveyn tutumları okul öncesi dönem çocukların prososyal davranışlarını yordamakta midir?

\section{YÖNTEM}

Araştırmada ilişkisel tarama modeli kullanılmıstır. Bu modele göre; iki veya daha çok değişken arasında değişimi belirlemek (Karasar, 2014) ve belirlenen değişkenler bakımından varyansın ne kadarının açıklandığının tespit edilebilmesi amaçlanmaktadır (Karakaya, 2012). Diğer bir deyişle bu çalışmada ilişkisel tarama modeli, aralarındaki ilişkinin incelendiği değişkenlerden hangisinin değişimi açıkladığını ve ne derecede açıkladığını ortaya koymak için kullanılmıştır. Çalışma grubunun belirlenmesinde amaçlı örneklem kullanılmıştır. Amaçlı örneklem, çalışma grubu hakkında güvenilir şekilde genelleme yapabilmek için rastgele seçilen büyük örneklemlerdir (Patton, 2014). Araştırmaya hız ve pratiklik kazandırılması açısından bu çalışmada, amaçlı örneklem yöntemlerinden kolay ulaşılabilir örneklem kullanılmıştır.

\section{Çalışma Grubu}

Çalışma grubu, Kilis ili Milli Eğitim Müdürlügüne bağlı merkez anaokullarına devam eden 25-72 ay aralığındaki 132 kız ve 158 erkek olmak üzere toplam 290 çocuktan (25-36 ay n:12, 36-47 ay n:87, 48-59 ay n:177 ve 60-72 ay n:14) oluşmaktadır.

Çalışma grubunu oluşturan çocukların \%45.5’i (n:132) kız, \%54.5’’ (n:158) erkek; \%4.13’ü (n:12) 25-35 aylık, \%30’u (n:87) 36-47 aylık, \%61.03’ü (n:177) 48-59 aylık ve \%4.83’ü (n:14) 60-72 aylık; \%10.3’ü (n:30) tek çocuk ve \%89.7’sinin (n:260) bir veya daha fazla kardeşi vardır. Ayrıca bu çocukların \%28.3’ü (n:82) 6 aydan daha az süredir okula devam ederken, \%71.7’si (n:208) 6 aydan daha fazla süredir okul öncesi eğitim kurumuna devam etmektedir. Çalışma grubunu oluşturan çocukların annelerinin \%58.4'ü (n:169) ilköğretim, \%23.7’si (n:69) ortaöğretim ve \%17.9’u (n:52) yükseköğretim mezunudur. Babaların \%42.75’i (n:124) ilköğretim, \%27.93’ü (n:81) ortaöğretim ve \%29.32'si (n:85) yükseköğretim mezunudur. 


\section{Veri Toplama Yöntemi}

Verilerin toplanmasında öncelikli olarak Çocuk Prososyallik Ölçeği’ni uyarlayan araştırmacılar ve Ebeveyn Tutum Ölçeği'ni geliştiren araştırmacılarla e-posta üzerinden iletişim kurularak ölçeğin sadece bu çalışma için kullanılacağına dair düzenlemiş oldukları “ölçek izin yazıları” doldurularak gerekli izin alınmıştır. Daha sonra çalışmanın gerçekleştirileceği il olan Kilis ili Milli Eğitim Müdürlüğünden gerekli resmi izin yazısı alınmıştır. Merkezde bulunan resmi ve bağımsız anaokullarına gidilerek çalışma annelere yüz yüze anlatılmıştır. Böylelikle çalışmaya istekli ve gönüllü olan anneler belirlenmiştir. Çalışmaya gönüllü olarak katılmak isteyen annelerden, gerekli form ve ölçekleri doldurmaları istenmiştir.

\section{Veri Toplama Araçları}

Verilerin toplanmasında; ebeveynler ve çocukların kişisel bilgileri için "Demografik Bilgi Form"u, çocukların prososyal becerilerinin belirlenmesi için "Çocuk Prososyallik Ölçeği (ÇPÖ)" ve ebeveyn tutumlarının belirlenmesi için "Ebeveyn Tutum Ölçeği (ETÖ)” kullanılmıştır.

Demografik Bilgi Formu: Anne ve babanın öğrenim düzeyi ile çocuğun yaşı, cinsiyeti, kardeş sayısı, okul öncesi eğitim kurumuna devam süresine ilişkin bilgilerin yer aldığı formdur.

Çocuk Prososyallik Ölçeği (ÇPÖ): Okul öncesi dönem çocuklarının prososyallik düzeylerini belirlemek amacıyla Bower (2012) tarafından geliştirilmiştir. Ölçek; Bağc1 ve Öztürk Samur (2016) tarafından geçerlik güvenirlik çalışması yapılarak Türkçe'ye uyarlanmıştır. Ölçek; çocukların davranışlarını değerlendirmelerine yönelik olarak anneler, babalar ve öğretmenler için üç ayrı formda hazırlanmıştır. Ölçeğin üç formu da tek boyutludur. Ölçek, çocuğun gösterdiği davranışların ne derecede prososyal davranışları içerdiğinin belirlenebilmesi için 1'den 5'e (hiçbir zaman, nadiren, bazen, genellikle ve her zaman) kadar likert olarak puanlanmaktadır. Çocukların prososyal davranışlarının yüksek olması ölçekten alınan yüksek puanla belirlenmektedir. Ölçeğin öğretmen ve baba formu 22 maddeden oluşurken, anne formu 21 maddeden oluşmaktadır. Yapılan uyarlama çalısması neticesinde ölçeğin güvenirlik katsayıları öğretmen formunda .96, anne formunda .91 ve baba formunda .92 değere sahiptir. Bu çalışma kapsamında kullanılan Çocuk Prososyallik Ölçeği- Anne Formu'na ilişkin 290 çocuk üzerinden toplanan veriler ile elde edilen güvenirlik katsayısının .889 olduğu tespit edilmiştir. Bu değer; Alpar’a (2014) göre .80-1.00 aralığında yer alması itibariyle ölçek için yüksek güvenilir sayılmaktadır. 
Ebeveyn Tutum Ölçĕ̆i (ETÖ): Ebeveyn Tutum Ölçeği (ETÖ), ebeveynlerin 2-6 yaş arasındaki çocuklarını yetiştirirken onlara karşı gösterdikleri ebeveyn tutumlarını ölçmek amacıyla Karabulut Demir ve Şendil (2008) tarafindan geliştirilmiştir. Toplamda 46 madde olan ölçek, 4 alt boyuttan (demokratik, otoriter, aşırı koruyucu ve izin verici) oluşmaktadır. 5'li derecelemeye göre puanlanan likert tipi olarak hazırlanan ölçeğin, boyutlarından alınan yüksek puan, ebeveynin o boyutun temsil ettiği davranışa yönelik tutumlar sergilediği anlamına gelmektedir. Ebeveyn Tutum Ölçeği’nin güvenirlik analizleri sonucunda; ölçek alt boyutlarının güvenirlik katsayıları demokratik alt boyutunda .83 , otoriter alt boyutunda .76 , aşırı koruyucu alt boyutunda .75 ve izin verici alt boyutunda .74 olarak tespit edilmiştir. Bu çalışma kapsamında Ebeveyn Tutum Ölçeği ile 290 çocuk üzerinden toplanan veriler ile elde edilen güvenirlik katsayıları şöyle sıralanmaktadır: Demokratik tutum .80, otoriter tutum .81, aşır1 koruyucu tutum .72 ve izin verici tutum .63 olarak tespit edilmiştir. Alpar’a (2014) göre değer aralıklarının .6-.79 olması ölçümün güvenilir olduğunu ve .801.00 aralığındaki değerlerin ölçek için yüksek güvenilir sayıldığı belirtilmektedir.

\section{Verilerin Analizi}

Verilerin analizinde t-testi, tek yönlü varyans analizi (ANOVA), Pearson moment çarpım korelasyon katsayısı ve aşamalı çoklu regresyon analizi kullanılmıştır. Kullanılan testlerin normallik varsayımının incelenmesine ilişkin grup büyüklüğü 50'den büyük olduğu için Kolmogorov-Smirnov testi yapılmıştır (Büyüköztürk, Çokluk ve Köklü, 2015). Ayrıca çarpıklık ve basıklık hesaplamaları da birlikte incelenmiştir.

Tablo 1. Normallik testi sonuçları

\begin{tabular}{llcccc}
\hline & & \multicolumn{2}{c}{ Kolmogorov-Smirnov } & Çarpıklik & Basıklik \\
& & $\mathrm{df}$ & $\mathrm{p}$ & & \\
\hline Çocuk Prososyallik Ölçeği & 290 & 200 & -.193 & -.121 \\
Ebeveyn Tutum Ölçeği & 290 & .200 & .066 & -.013 \\
Anne & İlköğretim mezunu & 169 & .200 & -.227 & -.204 \\
Öğrenim & Ortaöğretim mezunu & 69 & .200 & .048 & -.209 \\
Düzeyi & Yükseköğretim mezunu & 52 & $.041 *$ & -.436 & -.014 \\
Baba & Illköğretim mezunu & 124 & .200 & -.046 & -.402 \\
Öğrenim & Ortaöğretim mezunu & 81 & .200 & -.338 & .215 \\
Düzey & Yükseköğretim mezunu & 85 & .200 & -.213 & -.158 \\
& 25-35 ay & 12 & .200 & -.509 & .305 \\
Çocuğun & 36-47 ay & 87 & .200 & -.366 & .465 \\
Yaş1 & $48-59$ ay & 177 & .200 & -.129 & -.402 \\
& $60-72$ ay & 14 & .200 & -.857 & 1.457 \\
\hline
\end{tabular}


Tablo 1'de görüldüğü gibi Kolmogorov-Smirnov normallik testine göre puan dağglımları normal dağılım göstermektedir ( $\mathrm{p}>0.05)$. Her iki ölçeğin puan dağılımının çarpıklık-basıklık değerleri sıfıra yakın bulunmuştur. Çarpıklık ve basıklık katsayısının +1 ile -1 arasında bulunması normal dağılımdan manidar bir sapma olmadığını göstermektedir (Büyüköztürk, Çokluk ve Köklü, 2015). Anne öğrenim durumuna göre yükseköğretim kategorisinde normallik test sonucu .041 çıkmıştır $(\mathrm{p}<.05)$. Ancak çarpıklık ve basıklık değerleri göz önüne alındığında normallik varsayımı sağlandığ1 söylenebilir. Bu nedenle parametrik testler kullanılmıştır.

Araştırmanın amacına yönelik olarak veri setinin homojenliğinin test edilmesinde Levene f istatistiği sonuçları da incelenmiştir. Çalışmanın bağımlı değişkeni olan prososyal davranış puanlarının dağılımı normal olduğundan prososyal davranışların bağımsız değişken kategorilerine göre anlamlı farklılık gösterip göstermediği parametrik testler ile incelenmiştir. Çocuğun yaşı, anne ve babanın öğrenim düzeylerine göre tek yönlü varyans analizi (ANOVA) sonuçlarına yer verilmiştir. Çocukların yaşları, kardeş sayıları, cinsiyetleri ve okula devam sürelerine göre bağımsız gruplar ttesti yapılmıştır. Çocuk Prososyallik Ölçeği puanları ve incelenen diğer değişkenler arasındaki ilişkiyi belirleyebilmek için Pearson moment çarpım korelasyon katsayısı hesaplanmıştır. Bu teste göre lineerlik varsayımını sağlamayan İzin Verici Tutum alt boyutu ve kardeş sayısı regresyon analizine dahil edilmemiştir. Çoklu regresyon analizinin doğru sonuç vermesi için multicollinearity (çoklu bağlantılılık) için bağımsız değişkenler arası korelasyonlar $(\mathrm{r}=\leq .80)$, CI indeksi, tolerans ve VIF değerleri incelenmiştir. Tablo 6’ya göre herhangi iki bağımsız değişken arasındaki korelasyon .801.00 değer aralığında yer almamaktadır. Bu nedenle herhangi bir sınırlama söz konusu değildir. Ayrıca değişkenlere ait CI indeksi, tolerans ve VIF değerleri de göz önüne alınarak multicollinearity sorunu olmadığı söylenebilir. Uçdeğer analizi için değişkenlerin Mahalanobis uzaklıkları hesaplanmış ve $\mathrm{p}<.001$ düzeyinde anlamlı olan üç değişken belirlenmiştir. Bu üç değişken veri setinden çıarılmıştır. Açıklayıcı değişkenlerden çocuğun yaşı, cinsiyeti ve okul öncesi eğitim kurumuna devam süresi kategorik olup söz konusu bu değisskenler dummy olarak kodlandıktan sonra regresyon analizine dahil edilmiştir. Yaş değişkeni için '25-35 ay', cinsiyet için 'erkek' ve okula devam süresi için 'altı aydan az' kategorileri referans kategoriler olarak alınmıştır. Regresyon analizinde tüm anlamlı değişkenler modele eklenip stepwise metodu (aşamalı yöntem) uygulanmıştır.

\section{BULGULAR}

Okul öncesi dönem çocukların prososyal davranışlarının yaş, cinsiyet, kardeş sayısı, okul öncesi eğitim kurumuna devam süresi ve anne-babanın öğrenim düzeyi ve ebeveyn tutumları açısından 
incelenmesi ve bu değişkenlerin prososyal davranışlar üzerindeki yordayıcı etkisinin belirlenmesi amacıyla yapılan çalışmanın bulgularına aşağıda yer verilmiştir.

Tablo 2. Çocuk Prososyallik Ölçeği puanlarının betimsel istatistikleri

\begin{tabular}{lccc}
\hline Anne Öğrenim Düzeyi & $\mathrm{n}$ & $\overline{\mathrm{X}}$ & $\%$ \\
\hline İlköğretim mezunu & 169 & 3,76 & 58.27 \\
Ortaöğretim mezunu & 69 & 3,66 & 23.8 \\
Yükseköğretim mezunu & 52 & 3,85 & 17.93 \\
Toplam & 290 & 3,75 & 100.0 \\
\hline Baba Öğrenim Düzeyi & $\mathrm{n}$ & $\overline{\mathrm{X}}$ & $\%$ \\
\hline İlköğretim mezunu & 124 & 3,71 & 42.76 \\
Ortaöğretim mezunu & 81 & 3,77 & 27.93 \\
Yükseköğretim mezunu & 85 & 3,79 & 29.31 \\
Toplam & 290 & 3,75 & 100.0 \\
\hline Çocuğun yaş1 & $\mathrm{n}$ & $\overline{\mathrm{X}}$ & $\%$ \\
\hline 25-35 ay & 12 & 3,52 & 4.14 \\
36-47 ay & 87 & 3,66 & 30.0 \\
48-59 ay & 177 & 3,78 & 61.03 \\
60-72 ay & 14 & 4,11 & 4.83 \\
Toplam & 290 & 3,76 & 100.0 \\
\hline
\end{tabular}

Tablo 2'de yer alan bilgilere göre araştırmaya katılan annelerin \%58.7'si (n:169) ilköğretim, \%23.8’i (n:69) ortaöğretim ve \%17.93’ü (n:52) yükseköğretim mezunudur. Annelerin öğrenim düzeylerine göre çocuklarının prososyal davranıs puan ortalamaları; ilköğretim mezunu $(\overline{\mathbf{X}}=3,76)$, ortaöğretim mezunu $(\bar{X}=3,66)$ ve yükseköğretim mezunu $(\bar{X}=3,85)$ olarak görülmektedir. Babaların \%42.76's1 (n:124) ilköğretim, \%27.93’ü (n:81) ortaöğretim ve \%29.31’i (n:85) yükseköğretim mezunudur. Babaların öğrenim düzeylerine göre çocuklarının prososyal davranış puan ortalamaları; ilköğretim mezunu $(\overline{\mathbf{X}}=3,71)$, ortaöğretim mezunu $(\overline{\mathbf{X}}=3,77)$ ve yükseköğretim mezunu $(\overline{\mathbf{X}}=3,79)$ olarak sıralanmaktadır. Babaların öğrenim düzeyindeki ilerlemelerin çocukların prososyal davranış ortalamalarını artırdığı görülmektedir. Çocukların yaşları \%4.14’ü (n:12) 25-35 ay, \%30’u (n:87) 3647 ay, \%61.03’ü (n:177) 48-59 ay ve \%4.83’ü (n:14) 60-72 ay aralı̆̆ındadır. Çocuğun yaşı değişkenine göre prososyal davranış ortalamaları 25-35 ay, $\bar{X}=3,52$; 36-47 ay, $\bar{X}=3,66$; 48-59 ay, $\bar{X}=3,78$ ve 6072 ay, $\bar{X}=4,11$ olarak bulunmuştur. Bu sonuca göre çocukların yaşları arttıkça prososyal davranış ortalamaları da artmaktadır. 
Tablo 3. Çocuk Prososyallik Ölçeği puanlarının “anne öğrenim durumu, baba öğrenim durumu ve çocuğun yaşı" na göre tek yönlü varyans analizi (ANOVA) sonuçları

\begin{tabular}{|c|c|c|c|c|c|c|c|}
\hline & $\begin{array}{l}\text { Varyansin } \\
\text { Kaynağ1 }\end{array}$ & $\begin{array}{l}\text { Kareler } \\
\text { Toplamı }\end{array}$ & sd & $\begin{array}{c}\text { Kareler } \\
\text { Ortalamas1 }\end{array}$ & $\mathrm{F}$ & $\mathrm{p}$ & Anlamlı Fark \\
\hline \multirow{4}{*}{ Anne Öğrenim Düzeyi } & Gruplararas1 & 1.127 & 2 & .563 & \multirow{4}{*}{1.642} & \multirow{4}{*}{.195} & \\
\hline & Gruplariçi & 98.494 & 287 & .343 & & & \\
\hline & Toplam & 99.621 & 289 & & & & \\
\hline & Levene: 4.2 & $\mathrm{p}=.016^{*}$ & & & & & \\
\hline \multirow{4}{*}{ Baba Öğrenim Düzeyi } & Gruplararas1 & 0.353 & 2 & .176 & \multirow{4}{*}{.510} & \multirow{4}{*}{.601} & \\
\hline & Gruplariçi & 99.268 & 287 & .346 & & & \\
\hline & Toplam & 99.621 & 289 & & & & \\
\hline & Levene: 2.1 & $8, p=.116$ & & & & & \\
\hline \multirow{4}{*}{ Çocuğun Yaşı } & Gruplararas1 & 3.233 & 3 & 1.078 & \multirow{4}{*}{3.198} & \multirow{4}{*}{$.024^{*}$} & \multirow{4}{*}{$\begin{array}{l}60-72 \text { ay ile } 25-35 \text { ay } \\
60-72 \text { ay ile } 36-47 \text { ay }\end{array}$} \\
\hline & Gruplariçi & 96.388 & 286 & .337 & & & \\
\hline & Toplam & 99.621 & 289 & & & & \\
\hline & \multicolumn{2}{|c|}{ Levene: $1.090, p=.354$} & & & & & \\
\hline
\end{tabular}

${ }^{* \mathrm{p}}<.05$

Tablo 3’te Çocuk Prososyallik Ölçeği puanlarının, anne öğrenim düzeyi [F(2, 287)=1.6, p>.05] ve baba öğrenim düzeyi $[\mathrm{F}(2,287)=.51, \mathrm{p}>.05]$ bakımından istatistiksel olarak anlamlı bir fark oluşturmadığ1; çocuğun yaşına göre çocuğun prososyal davranış puan ortalamaları arasında anlamlı bir fark olduğu $[\mathrm{F}(3,286)=3.19, \mathrm{p}<.05]$ görülmektedir. Tukey çoklu karşılaştırma testine göre anlamlı fark 60-72 ay ile 25-35 ay ve 60-72 ay ile 36-47 ay arasındadır. Anne öğrenim düzeyine göre Levene Homojenlik Testi .016 çıkmıştır $(\mathrm{p}<.05)$. Test sonucuna göre homojen varyans varsayımı sağlanamadığı için ANAVO-F yerine Welch istatistiği hesaplanmıştır.

Tablo 4. Çocuk Prososyallik Ölçeği puanlarının “anne öğrenim durumuna” göre Welch istatistiği sonuçları

\begin{tabular}{llccc}
\hline Anne Ö̆̆renim Düzeyi & statistic & df1 & df2 & $\mathrm{p}$ \\
\hline Welch & 2.224 & 2 & 130.503 & .112 \\
\hline
\end{tabular}

Tablo 4’te görüldüğü üzere anne öğrenim durumuna göre Welch istatistiği sonucu p>.05 çıkmıştır. $\mathrm{Bu}$ sonuca göre Çocuk Prososyallik Ölçeği puanları “anne öğrenim durumuna” göre farklılaşmamaktadır. 
Tablo 5. Çocuk Prososyallik Ölçeği puanlarının "kardeş sayısı, cinsiyet ve okul öncesi eğitim kurumuna devam süresi”ne göre bağımsız gruplar t-testi sonuçları

\begin{tabular}{|c|c|c|c|c|c|c|c|c|c|}
\hline & & \multirow{2}{*}{$\mathrm{n}$} & \multirow{2}{*}{$\bar{x}$} & \multirow{2}{*}{ SS } & \multirow{2}{*}{ sd } & \multicolumn{2}{|c|}{ Levene } & \multirow{2}{*}{$\mathrm{t}$} & \multirow{2}{*}{$\mathrm{p}$} \\
\hline & & & & & & $\mathrm{f}$ & $\mathrm{p}$ & & \\
\hline \multirow{2}{*}{ Kardeş sayısı } & Tek çocuk & 30 & 3.61 & .62 & 288 & \multirow{2}{*}{.260} & \multirow{2}{*}{.610} & \multirow{2}{*}{1.393} & \multirow{2}{*}{.165} \\
\hline & Bir ve daha fazla kardeş & 260 & 3.77 & .58 & & & & & \\
\hline \multirow{2}{*}{ Cinsiyet } & $\mathrm{K} 1 z$ & 132 & 3.85 & .59 & 288 & \multirow{2}{*}{.025} & \multirow{2}{*}{.873} & \multirow{2}{*}{2.64} & \multirow{2}{*}{$.009 *$} \\
\hline & Erkek & 158 & 3.67 & .57 & & & & & \\
\hline \multirow{2}{*}{$\begin{array}{l}\text { Okul Öncesi Eğitim } \\
\text { Kurumuna Devam } \\
\text { Süresi }\end{array}$} & 6 aydan az (yeni başlayan) & 82 & 3.6 & .63 & 288 & \multirow{2}{*}{2.172} & \multirow{2}{*}{.142} & \multirow{2}{*}{2.761} & \multirow{2}{*}{$.006^{*}$} \\
\hline & 6 aydan fazla & 208 & 3.81 & .55 & & & & & \\
\hline
\end{tabular}
${ }^{* \mathrm{p}}<.05$

Tablo 5’te görüldüğü gibi Çocuk Prososyallik Ölçeği puanları kardeş sayısına [t(288)=1.39, p>.05] göre istatistiksel olarak anlamlı bir farkllılı göstermemektedir. Ölçek puanları çocuğun cinsiyeti $[\mathrm{t}(288)=2.64, \mathrm{p}<.05]$ ve okul öncesi eğitim kurumuna devam süresi $[\mathrm{t}(288)=2.76, \mathrm{p}<.05]$ bakımından istatistiksel olarak anlamlı bir farklılık göstermektedir. Kız çocukların prososyal davranış puan ortalamaları ( $\overline{\mathbf{X}}=3.85)$, erkek çocukların puan ortalamalarından $(\overline{\mathbf{X}}=3.67)$ daha yüksektir. 6 aydan daha fazla süredir okul öncesi eğitim kurumuna devam eden çocukların prososyal davranış puan ortalamaları $(\overline{\mathbf{X}}=3.81)$, yeni başlayanların puan ortalamalarına $(\overline{\mathbf{X}}=3.6)$ göre daha yüksektir.

Tablo 6. Çocuk Prososyallik Ölçeği puanı ve incelenen değişkenler arasındaki Pearson Korelasyon Katsayısı sonuçları

\begin{tabular}{|c|c|c|c|c|c|c|c|c|c|}
\hline Korelasyon & $\begin{array}{c}\text { Çocuk } \\
\text { Prososyallik } \\
\text { Ölçeği } \\
\text { (ÇPÖ) }\end{array}$ & $\begin{array}{c}\text { Demokratik } \\
\text { Tutum }\end{array}$ & $\begin{array}{l}\text { Otoriter } \\
\text { Tutum }\end{array}$ & $\begin{array}{l}\text { Koruyucu } \\
\text { Tutum }\end{array}$ & $\begin{array}{l}\text { İzin } \\
\text { Verici } \\
\text { Tutum }\end{array}$ & Yaş & $\begin{array}{c}\text { Kardeş } \\
\text { Sayısı }\end{array}$ & Cinsiyet & $\begin{array}{l}\text { O.Ö.E. } \\
\text { Kurumuna } \\
\text { Devam } \\
\text { Süresi } \\
\end{array}$ \\
\hline Çocuk & & & & & & & & & \\
\hline $\begin{array}{l}\text { Prososyallik } \\
\text { Ölçeği (ÇPÖ) }\end{array}$ & 1 & & & & & & & & \\
\hline $\begin{array}{l}\text { Demokratik } \\
\text { Tutum }\end{array}$ & $.314^{* *}$ & 1 & & & & & & & \\
\hline $\begin{array}{l}\text { Otoriter } \\
\text { Tutum }\end{array}$ & $-.124^{*}$ & $-.406^{* *}$ & 1 & & & & & & \\
\hline $\begin{array}{l}\text { Koruyucu } \\
\text { Tutum }\end{array}$ & $.121^{*}$ & $.357^{* *}$ & -.028 & 1 & & & & & \\
\hline $\begin{array}{l}\text { İzin verici } \\
\text { Tutum }\end{array}$ & .003 & -.014 & $.170^{* *}$ & .026 & 1 & & & & \\
\hline Yaş & $.167^{* *}$ & $.131^{*}$ & -.109 & $.139^{*}$ & .028 & 1 & & & \\
\hline Kardeş Sayısı & -.082 & .098 & -.081 & .097 & -.001 & -.035 & 1 & & \\
\hline Cinsiyet & $.154^{* *}$ & .023 & .005 & .038 & -.055 & -.020 & $-.151^{* *}$ & 1 & \\
\hline $\begin{array}{l}\text { O.Ö.E. } \\
\text { Kurumuna } \\
\text { Devam Süresi }\end{array}$ & $.161^{* *}$ & $.117^{*}$ & .004 & .025 & .064 & $.152^{* *}$ & $.138^{*}$ & .113 & 1 \\
\hline
\end{tabular}


Tablo 6'da Çocuk Prososyallik Ölçeği puanı ve incelenen değişkenler arasındaki korelasyonlar hesaplanmıştır. Çocuk Prososyallik Ölçeği puanları ile Demokratik Tutum alt boyutu arasında pozitif yönde ve orta düzeyde $(\mathrm{r}=.314, \mathrm{p}<.01)$; Otoriter Tutum alt boyutu arasında negatif yönde ve düşük düzeyde $(\mathrm{r}=-.124, \mathrm{p}<.01)$; Koruyucu Tutum alt boyutu arasında pozitif yönde ve düşük düzeyde $(\mathrm{r}=.121, \mathrm{p}<.01)$ anlamlı bir ilişki bulunmuştur. Çocuk Prososyallik Ölçeği puanları ile çocuğun yaşı arasında pozitif yönde ve düşük düzeyde ( $\mathrm{r}=.167, \mathrm{p}<.01)$, çocuğun cinsiyeti arasında pozitif yönde ve düşük düzeyde $(\mathrm{r}=.154, \mathrm{p}<.01)$, okul öncesi eğitim kurumuna devam süresi arasında pozitif yönde ve düşük düzeyde $(\mathrm{r}=.161, \mathrm{p}<.01)$ anlamlı bir ilişki bulunmuştur. Çocuk Prososyallik Ölçeği puanı ile Ebeveyn Tutum Ölçeği alt boyutu olan İzin Verici Tutum ve kardeş sayısı değişkeni dışındaki tüm değişkenlerde anlamlı doğrusal bir ilişki olduğu görülmektedir. $\mathrm{Bu}$ değişkenler lineerlik varsayımını karşılamadıklarından regresyon analizine dahil edilmemiştir.

Tablo 7. Prososyal davranışları yordayan değişkenler ve düzeyleri

\begin{tabular}{|c|c|c|c|c|c|c|c|c|c|c|c|}
\hline & Model & B & $\begin{array}{c}\text { Standart } \\
\text { Hata }\end{array}$ & Beta & $\mathrm{R}^{2}$ & $\mathrm{~F}$ & $\mathrm{t}$ & $\mathrm{p}$ & $\mathrm{Cl}$ & Tolerans & VIF \\
\hline \multirow[b]{2}{*}{1} & Sabit & 1.914 & .320 & & .105 & $33.29^{* *}$ & $5.973^{* *}$ & .000 & 1.00 & & \\
\hline & $\begin{array}{l}\text { Demokratik } \\
\text { Tutum }\end{array}$ & .437 & .076 & .323 & & & $5.770^{* *}$ & .000 & 19.37 & 1.00 & 1.000 \\
\hline \multirow{3}{*}{2} & Sabit & 1.857 & .318 & & .126 & $20.38^{* *}$ & $5.839^{* *}$ & .000 & 1.00 & & \\
\hline & $\begin{array}{l}\text { Demokratik } \\
\text { Tutum }\end{array}$ & .433 & .075 & .320 & & & $5.763^{* *}$ & .000 & 2.46 & .999 & 1.000 \\
\hline & Cinsiyet_k1z & .171 & .066 & .145 & & & $2.608^{*}$ & .008 & 21.99 & .999 & 1.000 \\
\hline \multirow{4}{*}{3} & Sabit & 1.889 & .316 & & .139 & $15.25^{* *}$ & $5.970^{* *}$ & .000 & 1.00 & & \\
\hline & $\begin{array}{l}\text { Demokratik } \\
\text { Tutum }\end{array}$ & .421 & .075 & .311 & & & $5.627^{* *}$ & .000 & 1.68 & .994 & 1.000 \\
\hline & Cinsiyet_kız & .173 & .065 & .146 & & & $2.651^{* *}$ & .007 & 2.50 & .999 & 1.000 \\
\hline & Çocuğun Yaşı & .320 & .151 & .117 & & & $2.116^{*}$ & .018 & 22.34 & .995 & 1.000 \\
\hline
\end{tabular}

Tablo 7'de görüldüğü üzere; öncelikli olarak aşamalı çoklu regresyon analizi ile çalışmada geçen değişkenler denenmiştir. Analiz ile denenen bu modellere göre ebeveyn tutumları, çocuğun cinsiyeti ve çocuğun yaşı değişkenlerinin Çocuk Prososyallik Ölçeği puanlarını yordama düzeyi incelenmiştir. Stepwise regresyon analizi üç adımda tamamlanmıştır. Analizin ilk adımında sadece demokratik tutum modelde yer almakta ve belirleyicilik katsayıs $\mathrm{R}^{2}=.105$ olmaktadır. İkinci adımda modele cinsiyet anlamlı değişken olarak girmiş ve belirleyicilik katsayısı .021 birim artmış ve $\mathrm{r}^{2}=.126$ olmuştur. Üçüncü adımda modele demokratik tutum ve cinsiyetin yanında yaş değişkeni modele girmiştir ve belirleyicilik katsayısnda .013 birimlik bir artış daha gerçekleşmiştir. Üçüncü adımda elde edilen regresyon modelinin bir bütün olarak anlamlı olduğu $(F=15.25 ; \mathrm{p}<.01)$ ve belirleyicilik katsayısının $\mathrm{R}^{2}=.139$ olduğu belirlenmiştir. Demokratik ebeveyn tutumu, cinsiyet ve yaş 
değişkenlerinin Çocuk Prososyallik Ölçeği puanlarının yaklaşık \%14’ünü açıkladığı görülmektedir. Regresyon sonuçları, demokratik ebeveyn tutum puanlarının $(B=.421 ; \mathrm{p}<.05)$, çocuğun cinsiyetinin $(\mathrm{B}=.173 ; \mathrm{p}<.05)$ ve yaşının $(\mathrm{B}=.320 ; \mathrm{p}<.05)$ Çocuk Prososyallik Ölçeği puanlarını pozitif yönde anlamlı olarak açıkladığını göstermektedir. Bu sonuçlara göre demokratik ebeveyn tutumu 1 puan fazla olan bir çocuğun prososyal puanının .421 puan daha yüksek olması beklenmektedir. Diğer değişkenler aynı iken kız çocukların erkek çocuklara göre Çocuk Prososyallik Ölçeği’nden aldıkları puanın .173 daha yüksek olması tahmin edilebilir. Ayrıca yaş kategorisi 60-72 ay olan bir çocuğun prososyal davranış puanı 25-35 ay kategorisindeki bir çocuğa göre .320 puan daha yüksek olması beklenmektedir.

\section{SONUÇ ve TARTIŞMA}

Bu çalışmada, okul öncesi dönem çocukların prososyal davranışlarının yaş, cinsiyet, kardeş sayısı, okul öncesi eğitim kurumuna devam süresi ve anne-babanın öğrenim düzeyi, ebeveyn tutumları açısından incelenmesi ve bu değişkenlerin prososyal davranışlar üzerindeki yordayıcı etkisinin belirlenmesi araştırılmıştır. Çocuğun prososyal davranışları ile yaşı arasında anlamlı bir fark olduğu; çocuğun yaşı büyüdükçe prososyal davranış puan ortalamalarının da artmakta olduğu belirlenmiştir. Daha büyük çocukların gösterdikleri prososyal davranışlar yaşça daha küçük çocukların değerleri ve zaman içindeki sosyal uyumuna göre nitelik olarak değişmektedir. Bakış açısı alma becerisinin yaşa göre anlamlı bir fark oluşturup oluşturmadığını gösteren çalışma sonuçlarına göre ise 6 yaşındaki çocukların 4 ve 5 yaşındaki çocukların algısal, bilişsel ve duyuşsal bakış açısı alma becerilerine göre daha yüksek puan ortalamasına sahip olduğu tespit edilmiştir (Bal ve Temel, 2014). Bebeklerin 10. ayında gözlemlenen empatik becerilerin (bilişsel ve duyuşsal olarak) yaşamlarının 2. yılındaki prososyal davranış düzeylerini yordadığı sonucuna ulaşılmıştır (Roth-Hanania, Davidov ve Zahn-Waxler, 2011). Bu sonuçların yanı sıra prososyal davranışların yaşla anlamlı bir şekilde ilişkili olmadığını gösteren sonuçlar da mevcuttur (Knudson ve Kagan, 1982). Çocukların küçük yaşlardan itibaren gösterdikleri prososyal davranışlar, farkındalıklarının yaşla birlikte artmasına bağlı olarak daha ileriki yaşlardaki prososyal davranışlar için tahmin edilebilir görülmektedir.

Cinsiyet değişkenine göre prososyal davranışlar incelendiğinde; kız çocuklarının prososyal davranışlarının, erkek çocukların prososyal davranış puanlarına göre daha yüksek olduğu ve istatistiksel olarak anlamlı bir farklılık gösterdiği belirlenmiştir. Yapılan bu çalışma ile tutarlılık gösteren diğer çalışma sonuçlarına göre kız çocukların daha yüksek prososyal davranış puanlarına sahip olduğu (Altay ve Güre, 2012; Bouchard ve diğerleri, 2015; Eisenberg ve Fabes, 1998; Hägglund, 1993; Yazıcı ve Salıkutluk, 2018) ve kız çocuklarının lehine prososyal davranış 
puanlarında istatistiksel açıdan anlamlı bir farklılığın olduğu sonucuna ulaşılmıştır (Yoleri ve Seven, 2014). Öte yandan Bağcı Çetin ve Öztürk Samur'un (2018) okul öncesi dönem çocukların prososyal davranışları ile anne ve babalarının prososyal davranışlanı arasındaki ilişkiyi inceledikleri çalışmada cinsiyet değişkeninin anlamlı bir fark oluşturmamasına rağmen, yapılan çalışma bulguları ile benzer şekilde kız çocukların puan ortalamalarının, erkek çocuklarınkinden daha yüksek olduğu tespit edilmiştir. Uzmen ve Mağden (2002) tarafindan paylaşma ve yardım etme davranışlarını içeren resimli çocuk kitapları ile verilen eğitimin kız çocuklarının yardım etme davranışı ve erkek çocukların paylaşma davranışları üzerinde daha etkili olduğu sonucuna ulaşılmıştır. Bu sonuçların yanı sıra Wan, Fu ve Tanenhaus (2019), Çin'de 4 yaş grubu 138 çocuk ile yaptıkları çalışmada eşgüdümlü olarak iş birliği yapmanın çocuklar arasında prososyal davranışları artırdığını ve erkek çocukların, verilen görevi tamamlarken bir başkasına yardım etmek ve yapıştırmalarını paylaşmak için daha istekli davrandıkları belirtilmektedir. Cinsiyetle ilgili bu farklılıkların daha çok kültürden kaynaklanan toplumsal cinsiyet rollerindeki beklentilerin ve oluşan kalıp yargıların neden olduğu düşünülebilir. Çocukların büyüdüklerinde nasıl birer yetişkin olacaklarına ilişkin, toplumun cinsiyete dayalı olarak onlardan beklediği rol ve sorumlulukları çocukların davranışlarını etkilemektedir. $\mathrm{Bu}$ şekilde öğrenilmiş olan cinsiyet rollerinde kız çocuklarına kültürel esneklik sağlanarak duygularını ifade etmelerine daha fazla fırsat verildiği düşünülmektedir. Bu durum kız ve erkek çocukların prososyal davranış gösterme eğilimlerini etkilemektedir.

Kardeş sayısı değişkenine göre Çocuk Prososyallik Ölçeği puan ortalamaları incelendiğinde; çocuğun bir veya daha fazla sayıda kardeşe sahip olması, kardeşinin olmamasına göre daha yüksek ortalamada prososyallik puanına sahiptir. Bu puan farkına rağmen çalışmada kardeş sayısı değişkenine göre istatistiksel olarak anlamlı bir farklılık bulunmamıştır. Öte yandan sahip olduğu kardeş sayıları açısından istatistiksel olarak anlamlı bir farklılık oluşturan ve kardeşi olanların, tek çocuk olanlara göre daha prososyal davranışlar sergilediğini belirten çalışmalar da mevcuttur (Bağc1 Çetin ve Öztürk Samur, 2018; Yenidede, 2018). Kardeşler arasındaki doğal ilişkilerin müdahalesiz olarak iki yıl boyunca gözlemlenmesiyle elde edilen sonuçlara göre prososyallik davranışlarının aralarındaki etkileşimlerle geliştiği belirtilmektedir (Tavassoli, Recchia ve Ross, 2019). Kardeşler arasındaki rahatlatıcı-teselli edici, duygu ve oyun paylaşımı ve yardım etme gibi davranışların prososyal davranışları desteklediği sonucuna ulaşılmıştır (Hughes, McHarg ve White, 2018). Kardeşleri olan çocukların birbirleriyle daha fazla etkileşimde olmalarının onların birbirlerini anlamalarını-gözlemlemelerini artırmasına daha çok fırsat sağladığı şeklinde değerlendirilebilir. Bu durumunda kardeşin olması, tek çocuk olanlara göre daha çok avantaj sağladığı ve prososyal davranışlar sergilemelerini daha fazla etkilediği düşünülebilir. 
Çocukların okul öncesi eğitim kurumuna devam edip etmeme durumları onların prososyal davranış gösterme eğilimlerini etkilemektedir. Okul öncesi eğitime devam süresi değisskenine göre 6 aydan daha fazla süredir bir okul öncesi eğitim kurumuna devam eden çocukların prososyal davranış puan ortalamaları, yeni başlayanlara göre daha yüksek olduğu sonucuna ulaşılmıştır. Gültekin Akduman, Günindi ve Türkoğlu'nun (2015) yaptığı çalışmada iki yıldan daha fazla süredir okul öncesi eğitime devam eden çocukların sosyal beceri puanlarında anlamlı bir farklılığın olduğu belirlenmiştir. Bu nedenle en az bir dönem okul öncesi eğitim kurumuna devam etmeleri çocukların gelecekteki davranışlarının şekillenmesinde fark yaratmaktadır. Çocukların okula devam etmeleri sosyal duygusal yönden gelişmelerini sağlayacak, çevrelerine ve kendi duygu-davranışlarına karşı farkındalıklarını artıracaktır.

Demokratik ebeveyn tutumu sergileyen annelerin, çocukların prososyal davranış puanlarını anlamlı düzeyde yordadığı belirlenmiştir. Yapılan çalışmalar incelendiğinde ebeveyn tutumları ve okul öncesi dönem çocukların prososyal davranışları kapsamında sınırlı çalışmaya ulaşılmasına rağmen prososyal davranışların kazanılmasında sosyal becerilerin önemli bir rol oynadığı söylenebilir. Demokratik ebeveyn tutumunun; 2006-2016 yılları arasında Türkiye'de yapılmıs olan yüksek lisans/doktora tezleri ve tezlerin kaynakçalarından ulaşılan makalelerin incelendiği meta analiz çalışmasına göre çocukların sosyal becerilerini olumlu yönde etkisi olduğu (Kırman ve Doğan, 2017); başlangıç, akademik destek, arkadaşlık ve duyguları yönetme beceri puanları arasında anlamlı bir ilişki olduğu tespit edilmiştir (Özyürek, 2015). Demokratik ebeveynlik tutumunu benimseyen ebeveynler ve çocukların empati davranışları arasında pozitif korelasyon bulunmuştur. Ayrıca demokratik ebeveyn tutumu, ebeveynlerin ön yargıları ve çocukların empati davranışları arasında arac1 rolü üstlenmektedir. Bu tutumu benimseyen ebeveynlerin ön yarg1 göstermedikleri ve bu durumun çocukların empati davranışlarını arttırdığı sonucuna ulaşılmıştır (Pontania ve Salim, 2019). Ebeveynler çocuklarına insanlara yardım etmenin gerekli olduğunu hatta böyle bir durumla karşı karşıya kalındığında yardım etme zorunluluğu hissetmelerini sağlamak için farkındalık oluşturmaktadır (Schuhmacher, Köster ve Kärtner, 2019). Çocukların toplum içinde kabul gören davranışları ilk olarak ailelerinden öğrendikleri gerçeği düşünülecek olursa anne-babaya ve hatta bakım veren kişiye önemli sorumluluklar düşmektedir. Ailelerin demokratik ebeveyn tutumunu benimsemelerinin teşvik edilmesi çocukların prososyal davranışlarını artıracaktır. Ayrıca çocuğun aile içinde prososyal becerilerini geliştiren deneyimler kazanması, toplum içinde daha fazla kabul göreceği ve dış dünyadaki ilişkilerinde daha başarılı olacağı düşünülmektedir.

Altay ve Güre (2012), annelerin ebeveynliği algılama stilleri ile prososyal davranış ilişkilerini incelediği çalışmasında otoriter ebeveynlik tutumu gösteren annelerin çocuklarının, izin verici 
ebeveynlik tutumu gösteren annelerin çocuklarından daha fazla prososyal davranış sergilediği sonucunu ortaya koymuşlardır. Durmuşoğlu Saltalı ve İmer (2018), ebeveynlerin davranışlarının (sıcaklık, olumlu katılım, cezalandırıcı) çocukların pek çok davranışının yordayıcısı olduğunu belirtmektedir. Ebeveynlerin bu davranışlarının çocukların prososyal davranışları, problem davranışları ve utangaçlık sergilemelerini ne derecede öngördüğü incelenmiştir. Bu çalışma sonuçlarına göre cezalandırıcı uygulamaların kullanıldığı ebeveynlik stilleri çocukların daha az prososyal davranış göstermelerine, bununla birlikte problem davranışlarında ve utangaçlıklarında artışa neden olmuştur. Ebeveynlerin davranışları çocukların toplumsal kabul sürecinde yaşamsal öneme sahip olan becerilerini etkilemektedir. Garcia ve diğerleri (2018) tarafindan yapılan çalışmada çocukların davranış problemlerine karşı olumlu ebeveyn-çocuk etkileşimlerini teşvik etmek üzere ebeveynlik müdahalesini içeren “Olumlu Ebeveynlik Programı” ile ebeveynlerin önceki olumsuz ebeveynlik uygulamalarına karşı içgörü kazandıkları, çocukların gelişimsel ihtiyaçlarını belirleyebildikleri, etkili disiplin yöntemleri uygulamaya başladıkları, etkili iletişim kurabildikleri belirtilmektedir. $\mathrm{Bu}$ sayede ebeveynler çocuklarına karşı daha fazla prososyal davranış gösterdiklerinde çocukların da onlara karşı davranışlarının değiştiği ve daha az problem davranış gösterdikleri ifade edilmektedir.

Sonuç olarak araştırmadan elde edilen bulgulara göre çocuğun yaşı büyüdükçe prososyal davranış puan ortalamalarının da artmakta olduğu; cinsiyet değişkenine göre kız çocuklarının prososyal davranış puanlarının, erkek çocuklarına göre anlamlı olarak daha yüksek olduğu belirlenmiştir. Okul öncesi eğitim kurumuna devam süresi değişkenine göre 6 aydan daha fazla süredir okul öncesi eğitim kurumuna devam eden çocukların prososyal davranış puan ortalamalarının, yeni başlayanlara göre daha yüksek olduğu bulunmuştur. Çocuk Prososyallik Ölçeği puanlarının annenin ve babanın öğrenim düzeyleri ile çocuğun kardeş sayısı bakımından istatistiksel olarak anlamlı bir fark oluşturmadığı görülmektedir. Ancak çocuğun bir veya daha fazla sayıda kardeşe sahip olması hiç kardeşinin olmamasına göre daha yüksek ortalamada prososyallik puanına işaret etmektedir. Ayrıca demokratik ebeveyn tutumu ve çocukların prososyal davranışları arasında pozitif yönde anlamlı bir ilişki olduğu tespit edilmiştir. Demokratik ebeveyn tutumunun, çocuğun cinsiyetinin ve artan yaşının okul öncesi dönem çocuklarının prososyal davranışlarını tahmin edici özellikte olduğu belirlenmiştir. Demokratik ebeveyn tutumu 1 puan fazla olan bir çocuğun prososyal puanının .421 puan daha yüksek olması beklenmektedir. Diğer değişkenler aynı iken kız çocukların Çocuk Prososyallik Ölçeği’nden aldıkları puanın erkek çocuklara göre .173 daha yüksek olması beklenmektedir. Ayrıca yaş kategorisi 60-72 ay olan bir çocuğun prososyal davranış puanı, 25-35 ay kategorisindeki bir çocuğa göre .320 puan daha yüksek olması beklenmektedir. Çalışma sonuçlarının 1şığında ileriki araştırmalar için şu önerilerde bulunulabilir. 
1. Prososyal davranışların gelişimi için öncelikle aileler erken yaşlarda çocuklarına empatik beceriler, paylaşma, yardımlaşma, rahatlatma-teselli edici davranışları öğreterek destek olmalılar. Okullarda uygulanan okul öncesi eğitim programlarında prososyal davranışların desteklenmesine yönelik içeriklerin yer alması sağlanabilir. Sonraki yapılacak olan araştırmalarda ise prososyal davranışların gelişimine yardımcı olmak için programlarda ne kadar süre ve hangi sıklıkta yer alması gerektiğine ilişkin yeni araştırmalar yapılabilir.

2. Kız çocuklarının prososyal davranışlarının desteklenmesi kadar erkek çocuklarına yönelik olarak girişimler başlatılmalıdır. Bu bağlamda erkek çocuklarının prososyal davranışlarının geliştirilebilmesi için toplumsal cinsiyet kalıplarından uzaklaşarak onların da kendilerini ifade etmelerine firsat verilmeli ve duygularını yaşamaları kız çocukları kadar desteklenmelidir. $\mathrm{Bu}$ durum aile ortamında olduğu kadar okul ortamında öğretmenler tarafından da desteklenmelidir. Araştırmacılar tarafından erkek çocukların prososyal davranışlarının gelişimleri üzerine çeşitli metotlar denenebilir.

3. Gelecek araştırmalarda kardeş sayısı bakımından prososyal davranış puan ortalamalarında farklılıkların nitel çalışmalar ile daha derinlemesine incelemesi yapılabilir.

4. Araştırmacılar ve öğretmenlerin, 3-6 yaş çocuğu olan aileleri okul öncesi eğitim kurumlarına göndermeleri için daha fazla bilinçlendirmeleri ve çeşitli desteklerle teşvik etmelerinin üzerine projeler yürütülebilir.

5. Demokratik ebeveyn tutumu sergileyen ebeveynler pek çok açıdan çocuklarıyla daha sağlıklı ilişki kurmaktadırlar. Bu tutuma yönelik ebeveynlik eğitimine ilişkin olarak öncelikle üniversiteler olmak üzere çeşitli eğitim kademelerinde eğitimler verilmelidir. Böylelikle ailelerin tutumları gereği çocuklarına karşı, çocukların da çevrelerine karşı daha duyarlı olacakları ve böylelikle toplum içinde prososyal davranış gösteren birey sayısının artacağı düşünülmektedir.

6. Gelecekteki araştırmalar için ebeveyn tutumlarına yönelik olarak çalışıllırken anne ve baba olmak üzere her iki ebeveyne ulaşılarak tutumların birlikte değerlendirilmesi sağlanabilir. Bu durumun çocuk yetiştirmede ne gibi benzerlikleri ve farklılıkları ortaya koyduğunu açıklamada daha fazla yardımcı olacağı düşünülmektedir.

\section{KAYNAKÇA}

Acar, I. H. ve Torquati, J. (2012). Prosocial behavior exhibited in preschool-aged children through nature-based activities. In Paper session presented at the annual meeting of Midwestern Educational Research Association, Evanston, IL.

Alpar, R. (2014). Spor, sağglk ve eğitim bilimlerinden örneklerle uygulamal istatistik ve geģerlik-güvenirlik. Ankara: Detay Yayıncilik. 
Altay, F. B. ve Güre, A. (2012). Relationship among the parenting styles and the social competence and prosocial behaviors of the children who are attending to state and private preschools. Educational Sciences: Theory and Practice, 12(4), 2712-2718.

Altıntaş, T. T. ve Bıçakçı, M. Y. (2017). Erken çocukluk döneminde prososyal davranışlar. The Journal of Academic Social Science Studies, 57, 245-261.

Bağcı Çetin, B. ve Öztürk Samur, A. (2018). 60-72 aylık çocukların prososyal davranışları ile annebabalarının prososyal davranışları arasındaki ilişkinin incelenmesi. Erz̧incan Üniversitesi Eüitim Fakültesi Dergisi, 20(1), 1-17.

Bağc1, B. ve Öztürk Samur, A. (2016). Çocuk ve yetişkin prososyallik ölçeklerinin geçerlik güvenirlik çalışması. Abi Evran Üniversitesi Kırşehir Ë̆̈tim Fakültesi Dergisi (KEFAD), 17 (3), 59-79.

Bal, Ö. ve Temel, Z. F. (2014). Okul öncesi eğitim kurumlarına devam eden 4-6 yaş çocuklarının kişiler arası problem çözme ve bakış açısı alma becerileri arasındaki ilişkinin incelenmesi. Trakya Üniversitesi Eğitim Fakültesi Dergisi, 4(1), 156-169.

Beaty, J.J. (1998). Observing Development of the Young Child. (4th. Ed.), Prentice-Hall, Inc., U.S.A.

Bee, H. L. ve Boyd, D. R (2009). Çocuk gelisim psikolojisi (O. Gündüz, çev.). İstanbul: Kaknüs yayınlar1

Beier, J. S., Gross, J. T., Brett, B. E., Stern, J. A., Martin, D. R. ve Cassidy, J. (2019). Helping, sharing, and comforting in young children: Links to individual differences in attachment. Child Development, 90(2), 1-17.

Bouchard, C., Coutu, S., Bigras, N., Lemay, L., Cantin, G., Bouchard, M. C. ve Duval, S. (2015). Perceived, expressed and observed prosociality among four-year-old girls and boys in childcare centres. Early Child Development and Care, 185(1), 44-65.

Bower, A. A. (2012). What we do when children are good: How parents reinforce their preschool children's prosocial behaviors, and the effectiveness of these strategies across contexts. (Master of Arts) University of Nebraska at Omaha, USA.

Brownell, C. A. (2013). Early development of prosocial behavior: Current perspectives. Infancy, 18(1), 1-9.

Brownell, C. A., Svetlova, M., Anderson, R., Nichols, S. R. ve Drummond, J. (2013). Socialization of early prosocial behavior: Parents' talk about emotions is associated with sharing and helping in toddlers. Infancy, 18(1), 91-119.

Büyüköztürk, Ş., Çokluk, Ö. ve Köklü, N. (2015). Sosyal bilimler için istatistik. Ankara: Pegem Akademi.

Caprara, G. V., Barbaranelli, C., Pastorelli, C., Bandura, A. ve Zimbardo, P. G. (2000). Prosocial foundations of children's academic achievement. Psychological Science, 11(4), 302-306.

Carlo, G. ve Randall, B. A. (2001). Are all prosocial behaviors equal? A socioecological developmental conception of prosocial behavior. Advances in Psychology Research, 2, 151-170. 
Chin, L. C. ve Zakaria, E. (2015). Effect of game-based learning activities on children's positive learning and prosocial behaviours (Kesan Aktiviti Pembelajaran Berasaskan Permainan terhadap Pembelajaran Positif dan Tingkah Laku Prososial Kanak-Kanak). Jurnal Pendidikan Malaysia | Malaysian Journal of Education, 40(2), 159-165.

Cigala, A., Mori, A. ve Fangareggi, F. (2014). Learning others' point of view: Perspective taking and prosocial behaviour in preschoolers. Early Child Development and Care, 185(8), 1199-1215.

Conte, E., Grazzani, I. ve Pepe, A. (2018). Social cognition, language, and prosocial behaviors: A multitrait mixed-methods study in early childhood. Early Education and Development, 29(6), 814-830.

Dereli, E. (2019). The relationship between prosocial behaviours, aggression types and moralsocial rule knowledge in preschool children. Cypriot Journal of Educational Sciences, 14(1), 042 055.

Doescher, S. M. ve Sugawara, A. I. (1989). Encouraging prosocial behavior in young children. Childhood Education, 65(4), 213-216.

Durmuşoğlu Saltalı, N. ve İmir, H. M. (2018). Parenting Styles as a Predictor of the Preschool Children's Social Behaviours. Participatory Educational Research, 5(2), 18-37.

Eisenberg, N. ve Fabes, R. (1998). Prosocial development (Meta-Analyses of Age and Sex Differences in Children's and Adolescents' Prosocial Behavior). In W. Damon \& R. M. Lerner (Editor-in-Chief) \& N. Eisenberg (Vol. Ed.) Handbook of child psychology: Vol. 3. Social, emotional, and personality development (5th ed., pp. 701-778). New York: Wiley.

Eisenberg, N. ve Mussen, P. H. (2003). The roots of prosocial behavior in children. Cambridge University Press.

Eisenberg, N., Guthrie, I. K., Murphy, B. C., Shepard, S. A., Cumberland, A. ve Carlo, G. (1999). Consistency and development of prosocial dispositions: A longitudinal study. Child Development, 70(6), 1360-1372.

Ferreira, T., Cadima, J., Matias, M., Vieira, J. M., Leal, T. ve Matos, P. M. (2016). Preschool children's prosocial behavior: The role of mother-child, father-child and teacher-child relationships. Journal of Child and Family Studies, 25(6), 1829-1839.

Garcia, A. R., DeNard, C., Ohene, S., Morones, S. M. ve Connaughton, C. (2018). "I am more than my past": Parents' attitudes and perceptions of the positive parenting program in child welfare. Children and Youth Services Review, 88, 286-297.

Gültekin Akduman, G., Günindi, Y. ve Türkoğlu, D. (2015). Okul öncesi dönem çocukların sosyal beceri düzeyleri ile davranış problemleri arasındaki ilişkinin incelenmesi. Journal of International Social Research, 8(37). 673-683.

Hägglund, S. (1993). The gender dimension in children's learning of prosocial competence in early educational settings. European Early Childhood Education Research Journal, 1(2), 67-80. 
Hastings, Utendale ve Sullivan, (2007). The socialization of prosocial development. In J. E. Grusec \& P. D. Hastings (Ed.) Handbook of socialization: Theory and research (pp. 638-664). Guilford Publications.

Hay, D. F. ve Cook, K. V. (2010). The transformation of prosocial behavior from infancy to childhood. In C. A. Brownell \& C. B. Kopp (Ed.) Socioemotional development in the toddler years: Transitions and transformations (pp. 100-131). Guilford Press.

Hepach, R., Vaish, A. ve Tomasello, M. (2013). A new look at children's prosocial motivation. Infancy, 18(1), 67-90.

Hughes, C., McHarg, G. ve White, N. (2018). Sibling influences on prosocial behavior. Current Opinion in Psychology, 20, 96-101.

Kakavoulis, A. K. (1998) Early childhood altruism: how parents see prosocial behavior in their young children, Early Child Development and Care, 140(1), 115-126.

Kandır, A. ve Alpan, U. Y. (2008). Okul öncesi dönemde sosyal-duygusal gelişime anne-baba davranışlarının etkisi. Aile ve Toplum, 14(14), 33-38.

Karabulut Demir, E. ve Şendil, G. (2008). Ebeveyn Tutum Ölçeği (ETÖ), Türk Psikoloji Yaz̨lar, 11(21), 15-25.

Karakaya, İ. (2012). Bilimsel araştırma yöntemleri. A. Tanrı̈ŏğen, (Ed.) Bilimsel Araștırma Yöntemleri (3. Baskı) (ss. 57-83). Ankara: Anı Yayıncllı.

Karasar, N. (2014). Bilimsel araştırma yöntemi (27. Baskı). Ankara: Nobel Yayın Dağıtım

Kırman, A. ve Doğan, Ö. (2017). Anne-baba çocuk ilişkileri: bir meta-sentez çalışması. Hacettepe Üniversitesi Sağhlk Bilimleri Fakültesi Dergisi, 4(1), 28-49.

Knafo, A. ve Plomin, R. (2006). Prosocial behavior from early to middle childhood: Genetic and environmental influences on stability and change. Developmental Psychology, 42, 771-786.

Knafo-Noam, A., Uzefovsky, F., Israel, S., Davidov, M. ve Zahn-Waxler, C. (2015). The prosocial personality and its facets: genetic and environmental architecture of mother-reported behavior of 7-year-old twins. Frontiers in Psychology, 6, 112.

Knudson, K. H. M. ve Kagan, S. (1982) Differential development of empathy and prosocial behavior. The Journal of Genetic Psychology: Research and Theory on Human Development, 140(2), 249-251.

López, F., Apodaca, P., Etxebarria, I., Fuentes, M. J. ve Ortiz, M. J. (1998). Conducta prosocial en preescolares. Infancia y Aprendizaje, 21(82), 45-61.

Mareš, J. (2017). Prosocial behavior education in children. Acta Technologica Dubnicae, 7(2), 7-16.

Milli Eğitim Bakanlı̆̆1 (MEB) (2013). Milli Ë̆̈itim Bakanlĭ̆ çocuk gelişimi ve eğitimi. Ablak gelişimi. 08 Mart 2020 tarihinde

http://www.megep.meb.gov.tr/mte_program_modul/moduller_pdf/Ahlak\%20Geli\%C5 $\% 9$ Fimi.pdf erişildi. 
Nowak-Fabrykowski, K., Dinçer, Ç., Lewandowska, E. ve Şen, M. (2013). Comparative analys is of young children's pro-social behaviors in the United States, Turkey, and Poland. International Journal of Early Childhood Education Research (IJECER), 5(2), 1-12.

Özyürek, A. (2015). Okul öncesi çocukların sosyal beceri düzeyleri ile anne tutumları arasındaki ilişkinin incelenmesi. Milli Ë̆gitim Dergisi, 45(206), 106-120.

Pastorelli, C., Lansford, J. E., Luengo Kanacri, B. P., Malone, P. S., Di Giunta, L., Bacchini, D., Bombi, A. S., Zelli, A., Miranda, M. C., Bornstein, M. H., Tapanya, S., Tirado, L. M. U., Alampay, L. P., Al-Hassan, S. M., Chang, L., Deater-Deckard, K., Dodge, K. A., Oburu, P., Skinner, A. T. ve Sorbring, E. (2016). Positive parenting and children's prosocial behavior in eight countries. Journal of Child Psychology and Psychiatry, 57(7), 824-834.

Patton, M. Q. (2014). Nitel Araştırma ve Değerlendirme Yöntemleri (B. Tarman ve M. F. Yiğit, Çev. Ed.). Ankara: Pegem Akademi.

Paulus, M., Becker, E., Scheub, A. ve König, L. (2016). Preschool children's attachment security is associated with their sharing with others. Attachment \& Human Development, 18(1), 1-15.

Pontania, A. R. ve Salim, R. M. A. (2019). The Relation of Child's Empathy and Parents' Prejudice: The Mediating Role of Parenting Style. Humaniora, 10(2), 105-112.

Roth-Hanania, R., Davidov, M. ve Zahn-Waxler, C. (2011). Empathy development from 8 to 16 months: Early signs of concern for others. Infant Behavior and Development, 34(3), 447-458.

Schuhmacher, N., Köster, M. ve Kärtner, J. (2019). Modeling prosocial behavior increases helping in 16-month-olds. Child Development, 90(5), 1789-1801.

Sterling Honig, A. S. (1982). Prosocial development in children. Young Children, 37(5), 51-62.

Svetlova, M., Nichols, S. R. ve Brownell, C. A. (2010). Toddlers' prosocial behavior: From instrumental to empathic to altruistic helping. Child Development, 81(6), 1814-1827.

Swit, C. ve McMaugh, A. (2012). Relational aggression and prosocial behaviours in Australian preschool children. Australasian Journal of Early Childhood, 37(3), 30-34.

Tavassoli, N., Recchia, H. ve Ross, H. (2019). Preschool children's prosocial responsiveness to their siblings' needs in naturalistic interactions: a longitudinal study. Early Education and Development, 30(6), 724-742.

Uzmen, S. ve Mağden, D. (2002). Okulöncesi eğitim kurumlarına devam eden altı yaş çocuklarının prososyal davranışlarının resimli çocuk kitapları ile desteklenmesi. Marmara Üniversitesi Atatürk Eğitim Fakültesi Ë̆itim Bilimleri Dergisi, 15(15), 193-212.

Vaish, A., Carpenter, M. ve Tomasello, M. (2009). Sympathy through affective perspective taking and its relation to prosocial behavior in toddlers. Developmental Psychology, 45(2), 534-543.

Wan, Y., Fu, H. ve Tanenhaus, M. K. (2019). Effects of coordination and gender on prosocial behavior in 4-year-old Chinese children. Psychonomic Bulletin \& Review, 26(2), 685-692. 
Warneken, F. (2015). Precocious prosociality: Why do young children help?. Child Development Perspectives, 9(1), 1-6.

Williams, K. E. ve Berthelsen, D. (2017). The development of prosocial behaviour in early childhood: Contributions of early parenting and self-regulation. International Journal of Early Childhood, 49(1), 73-94.

Yağmurlu, B., Sanson, A. ve Köymen, S. B. (2005). Ebeveynlerin ve çocuk mizacinın olumlu sosyal davranış gelişimine etkileri: Zihin kuramının belirleyici rolü. Türk Psikeoloji Dergisi, 20(55), 1 20 .

Yazıcı, Z. ve Salıkutluk Y.Z. (2018). Ebeveynlerin Prososyal Davranışlarıyla Çocukların Pro-sosyal Davranışları Arasındaki İlişki. İçinde A. Kodaman ve E. İ. Işıklı (Editörler), Sosyal, Beşeri ve İdari Bilimlerde Akademik Araștırmalar (ss. 411-430). Ankara: Gece Kitaplığ1.

Yenidede, E. E. (2018). 60-72 aylhk çocuklarm prososyal davranıslarna sosyal, duygusal ve bilisssel gelişimlerinin etkisinin incelenmesi. (Yayımlanmamış Yüksek Lisans Tezi) Maltepe Üniversitesi, İstanbul.

Yoleri, S. ve Seven, S. (2014). Analyzing effect of age and sex differences on prosocial behavior of preschool children. International Journal of Social Science, 29, 261-270. 